\title{
English Learning in Islamic Boarding School Al-Junaidiyah Biru Bone (Ethnographic Studies)
}

\author{
Suardi $^{1)}$, Emzir $^{2)}$, Zainal Rafli ${ }^{3)}$ \\ ${ }^{1)}$ STKIP DDI Mamuju, Mamuju, Indonesia \\ E-mail: suardi_lazuardy@yahoo.co.id \\ ${ }^{2)}$ State University of Jakarta, Indonesia \\ E-mail:emzir.unj@gmail.com \\ ${ }^{3)}$ State University of Jakarta, Indonesia \\ E-mail: zainal.rafli@unj.ac.id
}

\begin{abstract}
This study aims to analyze the process of learning English in Islamic boarding school AlJunaidiyah Biru Bone. Using ethnographic methods. The results of the study show that (1) analyzing the needs and the environmental context in the formulation of learning objectives, (2) using 2 curriculum that is the curriculum of 2013 for general subjects and the curriculum of special pesantren religious subjects, (3) adjustment of learning materials with context, social function , text structure, and linguistic elements, (4) using approach (Contextual Teaching and Learning-CTL), (5) Educators, and learners have a mutually exciting learning role to be interesting and fun, (6) developed language environments such as the implementation of English flag ceremonies, sports competitions and the arts that use English in extracurricular activities. The conclusion of the effort to habituate the use of English and has four language skills, namely listening, speaking, reading and writing.
\end{abstract}

Keywords: Learning, English, and Ethnography

\section{INTRODUCTION}

Given the importance of the role of English, then learning English in schools should be a great concern by the school. This is because learning English as the needs of students and the world of work. Apart from that, English is also a way to know the science globally, because it can not be denied that science is controlled by westerners who in fact use the English language. By that, English learning can be applied in schools.

Especially for the development of language skills of learners, Islamic boarding school has 3 institutions of extracurricular activities such as; 1) UNIBA (Language Unit), 2) Da'wah Unit, 3) English Forum. All three institutions have their respective duties and authorities. UNIBA (Language Unit) has responsibility for the implementation of English language guidance in the evening. English learning in the evening as part of extracurricular activities. Extracurricular activities conducted in the evening that is in the form of language class guidance for 2 nights of meetings in a week. The limitation of guidance time because students also have other responsibilities as learners of boarding school such as yellow book recitation and memorize al-Qur'an.

In addition, UNIBA's duties and responsibilities are the implementations of Gebyar. Gebyar which is a race of activities nuanced in English. Gebyar held the end of the semester as entertainment and competitions, competing for language skills, and talent competition for students. Students who champion will later represent the Islamic boarding school Al-Junaidiyah Biru Bone to 
participate in various regional, provincial, and national scale events.

English Learning

Learning is a term that refers to the conscious knowledge of the language, the knowledge of language rules. Learning leads to the achievement of competence that can be seen in the expertise of learners perform communication steps. According to Brown (2006: 6), learning is "the acquisition or acquisition of knowledge about a subject or a skill with learning, experience or instruction".

Similarly, according to Kimble and Garmezy in Brown (2006: 6) the definition of teaching implicit in the first definition of learning, can be defined as "to show or help a person learn how to do something, instruct, guide in the assessment, prepare knowledge, make know or understand".

In line with the above statement Wager (1992: 3) also said that learning is "a device of events that give effect in such a way to learners who learn so that the learning process occurs". These events give effect to learners in learning so that influence is an external influence to learners who learn. Furthermore, according to Rickey (1986: 10) what is meant by the design of learning is "the science of creating development, evaluation, and sustainability of the situation. Specifically and in detail which is a facility of learning ".

Oemar Hamalik (2009: 24) lessons related to curriculum objectives and plans, focused on methodological issues, such as teaching techniques, resource implementation activities, and measurement tools used in special teaching-learning situations.

Learning Objectives English

The main component that must be made by an educator is to formulate the objectives in teaching and learning activities (KBM). According to Cameron (2001: 28) defines the purpose of learning is learning goals are objectives or intended learning for particular learners aims of book or syllabus. Objectives have an important role in KBM because clear objectives can provide a clear direction for the selection of learning materials, the selection of appropriate methods, the use of appropriate props, and the development of evaluation tools implemented.

According to Cronton (1989: 56), learning objectives are "statements about the knowledge and abilities expected of learners after completion of learning". As Brown (2006: 165) distinguishes goals and objectives ie goals that are broader with objectives and purposes in the educational context, overall program, institution, or perhaps major modules within a language institution. While objectives are more specific than the goals both in terms of picture and context.

Learning Materials

Learning materials are one important element in language learning because learning the language means learning everything that is related to the language through the material. Tomlinson (2007: 2) states that teaching materials or learning materials are anything that can be used to facilitate language learning. From the definition explained that learning materials can be applied in English learning. In addition, VanTassel-Baska (2015) adds that learning materials such as literature (poetry, essays, biographies, and others), writing (narrative, expository, persuasive, and other), language study (grammar, vocabulary, and others), oral communication (discussion, interview, listening, debate, etc.) can be applied to specific learners who have more talent and intelligence.

To construct learning that is in context and meaning, it is necessary to use authentic materials. Villegas Rogers and Medley in Shrum and Glisan (200: 58) state that "authentic matter reflects a naturality of form and accuracy of situational and cultural context". According to Tagliante (2006: 71), the teaching material in the teaching of a foreign language is "recueils de documents et d'activités de classe qui suivent une progression et se réclament d'une méthodologie donnée". Good teaching English material, which contains an explanation of the steps that should be done by the teacher, cultural information, activities that need to be provided by the teacher, and others.

English Language Learning Approach and Method

The terms "approach", "method", and "technique" are often mixed when there is a difference between one another. Anthony in Richards and Rodgers (2003: 28), explains that; Approach is a set of assumptions about the nature of language learning and philosophical learning ". That is, the approach is a set of axiomatic assumptions about the nature and nature of language, language teaching, and language learning. While Nunan (2003: 4) defines the methodology or learning method as everything related to the process of choosing, organizing, and providing learning tasks and experiences. The method focuses on the techniques and steps of the learning activity to be applied.

The learning method is a way or the ability of educators in delivering particular learning materials in the classroom. The method is a method used to implement the plan that has been arranged in its activities so that the objectives that have been prepared are achieved optimally. 


\section{Language Environment}

Such limitations and situations illustrate that the language environment is the situation of a particular region in which a language grows, develops and is used by its speaker. The language environment According to Dulay, Burt, and Krashen (1982: 13), the language environment is "everything that the learner hears and sees about language can then learn."

According to Wardhaugh (2006: 119) that the language environment is a community environment can communicate using the same language, variations of the same language, and use the same language code. The environment has an important role in language acquisition. Therefore, from this perspective, according to Dulay, Burt, and Krashen (1982: 13) there are two language environments that allow language learners to get input on the language they learn, namely "the formal language environment and natural language environment".

\section{RESEARCH METHOD}

The method used in this research is Ethnography by using qualitative approach. The ethnographic method intended in this study is to explain all aspects of the existing culture of the implementation of English language learning. This research was conducted in Islamic boarding school Al-Junaidiyah Biru Bone. So the focus of the research will be more focused on the source of information and data from the parties, key informants and stakeholders are directly related.

\section{RESULT AND DISCUSSION}

\section{A. Teachers Formulate the Purpose of English Learning}

Determination of the process of formulation of learning objectives, the educators perform needs analysis and needs analysis context in the community. The goal is that the competence of learners in English correlates with the needs of the world of work. While the objectives are specifically contained in the syllabus and learning implementation plan (RPP) for each meeting. All of these goals lead to the ability to understand them well and can be realized in four skills - listening, speaking, reading and writing.

B. Application of Curriculum (Syllabus and RPP) English Learning

The curriculum used by Islamic boarding school Al-Junaidiyah Biru Bone uses 2 curriculum that is curriculum which refers to Kemendikbud with the curriculum of 2013 special subjects and curriculum of special pesantren religious subjects. The existence of 2 curricula is because Islamic boarding school Al-Junaidiyah Biru Bone has a learning system not only on religious lessons alone. However, there are also general subjects. Preparation of syllabus prepared in detail about $\mathrm{KI}$ and $\mathrm{KD}$ selected materially, learning, time allocation, media, and learning resources. While the RPP is based on indicators that use the operational verbs to achieve learning objectives.

\section{Learning Materials Used}

English learning materials include; composing very short and simple interpersonal text interactions involving greeting, saying goodbye, thanking and apologizing, and responding to the context of their use and taking into account the correct and appropriate social functions, text structures, and linguistic elements.

\section{Choosing Approaches and Methods Used}

Various learning approaches have been applied, each approach has its own advantages and disadvantages, but the most frequently applied approach is the Contextual Teaching and Learning (CTL) approach in English learning. Selection of learning methods in the classroom is very varied and not monotonous one method only, tailored to the background of learners and learning materials. Sometimes educators give lectures, questions, answers, role-playing, assignments or exercises, and become models for learning and teaching.

E. The Role of Educators, and Learners in English Learning

- The Role of Educators

The ability of educators or the competence of educators in the field of cognitive such as mastery of subject matter, knowledge of how to teach, knowledge of process assessment. Competence in the field of attitude, such as tolerance, has the will to improve its work. Behavioral competencies, such as teaching skills, guiding, assessing, using aids, learning, skills to foster learning spirit, skill in developing learning plans.

- Role of Learners

Learners in following the learning process in having a high motivation in learning English. This is seen from the awareness of learners in doing and completing the tasks provided by educators. 


\section{F. The Linguistic Environment Created and} Developed

- Formal Environment

There are several learning processes in the English language in a formal environment such as; the learning process situation in the classroom which is guided by the educator.

- The Natural Environment

There are several learning processes in the English language in the informal environment such as; various situations such as when communicating in a dormitory, in a mosque, in a dining area, while watching $\mathrm{TV}$, communicating with friends or with others, communication in the classroom, communication in pesantren environment, flag ceremonies using English or art and sport competitions using the English language as well as various other situations that occur naturally. In addition, there are some extracurricular activities that require the use of English.

\section{CONCLUSIONS}

Based on the research findings, it can be concluded that (1) analyzing the needs and environmental context in the formulation of learning objectives, (2) using 2 curriculum that is the curriculum of 2013 special subjects and the curriculum of special pesantren religious subjects, (3) adjustment of learning materials with context, social function, text structure, and linguistic elements, (4) using approach (Contextual Teaching and LearningCTL), (5) Educators, and learners have an interconnected role of learning to be interesting and fun, (6) developed languages such as the implementation of English flag ceremonies, sports competitions, and arts that use English in extracurricular activities.

\section{REFERENCES}

Baska, Joyce VanTassel. (2003). Differentiating the Language Arts for High Ability Learners, in the journal of the ERIC EC Digest, http://www.nagc.org/index.aspx?id=167.

Brown, H. Douglas. (2006). Principles of Language Learning and Teaching translated by Noor Cholis and Yusi Avianto. Jakarta: Kedutaan Besar Amerika Serikat.

Briggs, Gagne, Wager. (1992). Principles of Instructional Design. New York: Holt, Rinehat \& Winston.
Cameron, Lynne. (2001). Teaching Languages to Young Learners. United Kingdom: Cambridge University Press.

Cronton, Patricia. (1989). Planning Instruction for Adult Learners. Toronto: Wall \& Emerson. Inc.

Dulay, Heidi, Marina Burt dan Stephen Krashen. (1982). Language Two. New York: Oxford University Press.

Hamalik, Oemar. (2009). Dasar-Dasar Pengembangan Kurikulum. Bandung: Remaja Rosdakarya.

Nunan, David. (2003). Practical English Language Teaching. New York: Mc Graw Hill.

Richards, Jack C, and Theodore S. Rodgers. (2003). Approaches and Methods in Language Teaching. London: Cambridge University.

Rickey, Rita. (1986). The Theoretical and Conceptual Bases of Instructional Design. New York: Nichols Publishing.

Shrum, Judith L, and Eileen W. Glisan. (2000). Teacher's Handbook: Contextual Language Instruction. Amerika: Heinle \& Heinle.

Tagliante, Christine. (2006). La Classe de Langue. Paris: CLE International.

Wardhaugh, Ronald. (2006). Sociolinguistics. Victoria: Blackwell Publishing. 